\title{
Studies on Age and Growth of African Pike Hepsetus odoe in Ado Ekiti Reservoir
}

\author{
Idowu E. O. \\ Ekiti State University,Department of Zoology, Ekiti State, Ado-Ekiti, Nigeria.
}

\begin{abstract}
Age and growth pattern of African pike Hepsetus odoe from Ado-Ekiti Reservoir, Nigeria, were studied from May 2002 - May 2005. Samples were collected from the landing centres of fishermen in the reservoir. Age and growth were determined from length frequency distribution using Pauly's Integrated Method. Regression coefficient (3.61) showed positive allometric growth of the species. Condition factor significantly correlated with fish weight $(P \leq 0.05, r=0.60)$ and varied with season. Four distinct modes indicating the presence of four year classes at length $17.0 \mathrm{~cm}, 21.8 \mathrm{~cm}, 24.9 \mathrm{~cm}$ and $27.3 \mathrm{~cm}$ corresponding to age

$0^{+}, 1^{+}, 2^{+}$sand $3^{+}$respectively were observed. The asymptotic length $\left(L^{\infty}\right)$ was $35.30 \mathrm{~cm}$ with growth coefficient of 0.36 per year.
\end{abstract}

Keywords: Age, growth, Hepsetus odoe, Ado-Ekiti Reservoir

\section{Introduction}

The African pike, Hepsetus odoe (Bloch, 1974) is the only species of the Family Hepsetidae. It is a freshwater fish widely distributed in rivers and freshwater lagoon systems of Africa [1,2, 3, 4,5,6,7,8, and 9].

Age determination in fish species is essential for good fisheries management [10]. [11]Stated that more complete understanding of factors affecting maximization for fish growth would contribute importantly to fundamental biology of one of the more successful animal groups and give improved insight into various problems of fish culture and fisheries management. Age and growth studies are of practical importance for describing the status of fish population and for predicting the potential of fisheries [12]

Determining the age of tropical fishes is of particular concern as it is often difficult because there are no definite demarcated seasons and hence no clear annual rings on the hard structures [13, 14, and 15]. The Integrated Method of length frequency by [16] is adequate for aging and determining the growth pattern of fish. The greatest merit of this method is that it is very economical to use since only length measurements have to be taken; the costly process of age interpretation from hard parts of fish is avoided. The method also overcame the primary disadvantage in the use of hard parts for age determination of fish species since the fish must be sacrificed and to some degree mutilated. If samples are to be collected where there are commercial fish processing facilities, mutilation may make the fish less marketable.

Many workers have used length frequency method to estimate the age of many tropical fish species whose reproductive period is confined to a short period during the year. These include[17] on the clupeid, Ethmalosa fimbriata,[18]on catfish Clarias walkeri, [19] on the ten ponder Elops lacerta, [20] on the African bony-tongue Heterotis niloticus, [21] on the snout fish, Mormyrus rume, and [22] on the butter fish, Schilbe mystus. Previous studies on $H$. odoe have been concentrated on food and feeding habits [23] in Volta Lake, [24] in Kainji Lake, [25] in Lekki Lagoon; [5] in Zambezi River flood plain and [7] in Ado-Ekiti Reservoir.

H. odoe is an economically important fish in Nigerian freshwaters and particularly in Ado-Ekiti Reservoir where it forms part of the major commercial catch. Despite its importance, there is dearth information on this species from the reservoir. The present study was carried out therefore to investigate the age and growth of $H$. odoe in Ado-Ekiti Reservoir to provide information on the age of species in the reservoir, pattern of growth and maximum age/size attainable, also mortality. These are useful in the exploitation and management of the fish species in the reservoir.

\section{Study Area}

\section{Materials and Methods}

Ado-Ekiti Reservoir was constructed by damming River Ireje in Ado-Ekiti, Ekiti State, Nigeria in 1958. The Reservoir is a major source of water supply for domestic uses and also supports artisanal fisheries $[26,8]$. The Reservoir lies between latitude $7^{0} 35^{\prime}-7^{0} 36$ North and Longitude $5^{0} 12^{\prime}-5^{0} 13^{\prime}$ East at an altitude of about $440 \mathrm{~m}$ above sea level (Figure 1). The Topography of the reservoir is undulating and surrounded by highlands. Ado-Ekiti lies within the tropical rainforest zone of South-Western Nigeria and experiences a distinct dry season (from November to March) and rainy season (from April to October). 
The adjourning vegetation is dominated by: Elephant grass (Pennisetum purpureum), Giant star grass (Cynodon plectostachyum), Rhodes grass (Chlorisguyanana) and Siam weed (Eupatorium odorantum). The ichthyofauna consists of the tilapias, Tilapia zillii, Sarotherodon galileaus, Sarotherodon melanotheron and Oreochromis niloticus; catfishes, Chrysichtys nigrodigitatus, Clarias gariepinus, and Heterobranchus bidorsalis; H. odoe as well as the barb, Barbus sp.

\section{Collection of fish samples}

Weekly samples of $H$. odoe were obtained from the landing centres of fishermen from the reservoir between May 2002 and May 2005. The specimens were transferred in an ice chest for preservation by deep freezing prior to examination. In the laboratory each specimen was measured, weighed and given a registration number. The total length was taken as the distance from the tip of the snout with mouth closed to the end of the longest projection of the caudal fin while the standard length was taken as the distance from the snout with mouth closed to the base of the caudal fin. Both measurements were to the nearest tenth of a centimetre. The weights were taken on a Santorious Sensitive Balance to the nearest tenth of a gram. The length-weight relationship of the species was represented by the equation.

$\mathrm{W}=\mathrm{aL}^{\mathrm{b}}$

Where

$\mathrm{W}=$ weight in grams,

$\mathrm{L}=$ length in centimetres and ' $\mathrm{a}$ ' and ' $\mathrm{b}$ ' are regression constants.

This relationship was transferred into a linear form by the equation.

$\log \mathrm{W}=\mathrm{a}+\mathrm{b} \log \mathrm{L}$

The condition factor $(\mathrm{k})$, which refers to the degree of well-being of a fish (Fulton, 1902) was calculated monthly. Calculations were made separately for both sexes and combined sexes. The condition factor was calculated using the formula.

$\mathrm{K}=\frac{100 \mathrm{~W}}{\mathrm{~L}^{\mathrm{s}}}$

Where $\mathrm{K}=$ condition factor,

$\mathrm{W}=$ weight in grams and

$\mathrm{L}=$ standard length in centimetres

\section{Length frequency distribution (Peterson method)}

Monthly charts of the various standard lengths of the specimens were recorded with the frequency with which each length occurred.

Length - frequency polygons were obtained and the mean of such progressions were plotted against time to obtain the growth rate of species [27]. The method assuming that the peaks on the length frequency data represent distinct age groups.

The Integrated Method of length frequency [16] which combines the Peterson Method and Modal class Progression Analysis was also used in interpretation of growth pattern. This method is an attempt to draw a growth curve with a curved ruler directly upon the length - frequency obtained from samples sequentially arranged in time. The modal lengths were interconnected by peaks which corresponded to various ages and they were read off the curve.

The Integrated Method helps to overcome some of the uncertainties faced by both Peterson Method and Modal class progression Analysis.

\section{Growth parameters}

$\mathrm{L}_{\mathrm{t}}=\mathrm{L} \quad \infty\left[\left(1-\mathrm{e}^{(-\mathrm{k})}\left(\mathrm{t}-\mathrm{t}_{\mathrm{o}}\right)\right]\right.$

The length frequency data was subjected to [28] growth formula described by[16].

Where

$\mathrm{L}_{\infty}=$ mean fish length if they were to grow to a very old age (i.e. infinitely old fish).

$\mathrm{K}=$ growth coefficient (that shows how fast the fish approaches $\mathrm{L}_{\infty}$ )

$\mathrm{t}_{\mathrm{o}}=$ the "age" the fish would have at length zero, if they had always grown according to the equation (i.e. time when fish has zero length).

$\mathrm{L}_{\mathrm{t}}=$ Length at age $\mathrm{t}(\mathrm{cm})$

Then, the growth annually is gotten from:

$$
\mathrm{L} \frac{(\mathrm{t}+1.0)}{1.0}=\mathrm{L}_{(\mathrm{t})}
$$

The growth rate is defined by the equation: 
$\frac{\Delta \mathrm{L}}{\Delta \mathrm{t}}=\frac{\mathrm{L}(\mathrm{t}+\Delta \mathrm{t})-\mathrm{L}(\mathrm{t})}{\Delta \mathrm{t}} \mathrm{cm} /$ year

The mean length is obtained thus,

$\frac{\mathrm{L}(\mathrm{t}+1)+\mathrm{L}(\mathrm{t})}{2}$

The parameters $\mathrm{L}_{\infty}$ and $\mathrm{K}$ were obtained from Gulland - Holt plot of growth rate against the mean length $\mathrm{k}=\mathrm{b}$ (the negative slope).

Estimation of total mortality was made by applying formula of [29].

$\mathrm{Z}=\frac{\mathrm{K}(\mathrm{L} \infty-\mathrm{L}}{\mathrm{L}-\mathrm{L}^{1}}$

Where

$\mathrm{L}_{\infty}$ and $\mathrm{K}=$ parameter of Bertalanffy's growth equation

$\mathrm{L} \quad=$ mean length in catch $(\mathrm{cm})$

$\mathrm{L}^{1} \quad=$ smallest length that were fully represented in catch samples

$\mathrm{Z} \quad=$ total mortality

The growth performance index (GPI) of the species was computed from the formula described in [30]:

$\mathrm{GPI}=\log \mathrm{K}+2 \log \mathrm{L}_{\infty}$

Age determination from Peterson Method

\section{Result}

The length frequency distribution of $H$. odoe (Fig.2) shows different peaks / modes. Mean length at each mode and age were $17.0 \mathrm{~cm}\left(\right.$ Age $\left.0^{+}\right), 22.0 \mathrm{~cm}\left(\right.$ Age $\left.1^{+}\right), 25.0 \mathrm{~cm}\left(\right.$ Age $\left.2^{+}\right)$and $28.0 \mathrm{~cm}\left(\right.$ Age $\left.3^{+}\right)$.

\section{Age determination from Integrated Method}

The growth curve drawn directly upon length frequency data sequentially arranged in time is illustrated in Figure 3. Four distinct modes were observed. A smooth curve interconnecting the peaks cut succeeding horizontal lines at lengths $17.0 \mathrm{~cm}, 21.8 \mathrm{~cm}, 24.9 \mathrm{~cm}$ and $27.30 \mathrm{~cm}$ corresponding perhaps to age $0^{+}, 1^{+}, 2^{+}$and $3^{+}$ respectively.

\section{Von Bertalanffy Growth Methods}

Growth parameters obtained is fitted into Von Bertalanffy growth model. The fastest growth rate (4.80) was between age $0^{+}$and $1^{+}$, followed by the rate between $1^{+}$and $2^{+}$. The slowest rate of growth was between age $2^{+}$and $3^{+}$(see table 1$)$. The mean length of the fish in the reservoir $(23.11 \mathrm{~cm})$ falls within the age $2^{+}$as could be seen in Table 1 . This was the most frequent length.

Gulland - Holt plot of the growth rate against the mean length is illustrated in Figure 4. The growth curvature coefficient parameter $(\mathrm{K})$ was 0.36 . The mean fish length $\mathrm{L}_{\infty}$ of $35.30 \mathrm{~cm}$ was obtained if they were to grow to a very old age.

Mortality of the species in the reservoir was $0.37 \mathrm{yr}^{-1}$.

The growth performance index (GPI) was 2.62.

\section{Length - Weight Relationship}

647 specimens of H.odoe (standard length 12.50 to $29.80 \mathrm{~cm}$ body weight, 10 to $385 \mathrm{~g}$ ) were examined for their length - weight relationship and condition-factor. Longarithmic transformation of length weight reslationships of female and male H.odoe and both sexes combined are represented by the following regression equations.

Males: $\log \mathrm{W} \quad=-2.57+3.50 \operatorname{LogL}(\mathrm{r}=0.89, \mathrm{n}=342)$

Females: $\log \mathrm{W}=-3.00+3.81 \log \mathrm{L}(\mathrm{r}=0.92, \mathrm{n}=305)$

Both sexes $; \log W=-2.73+3.61 \log L(r=0.90, n=647)$.

\section{Condition Factor}

The mean condition factor $(\mathrm{K})$ for male, female and combined sexes were $1.28 \pm 0.25,1.24 \pm 0.22$ and $1.26 \pm 0.24$ respectively. The relationship of the fish's condition factor and body length for males, females and combined sexes were insignificant $\mathrm{r}=0.26, \mathrm{r}=0.46$ and $\mathrm{r}=0.33$ respectively $(\mathrm{P}>0.05$ level). The correlation coefficient between the fish's condition factor and body weight were significant for both females and males and combined sexes of H.odoe ( $\mathrm{r}=0.69, \mathrm{r}=0.57, \mathrm{r}=0.62$ respectively).

Monthly variation in the condition factor is illustrated in Figure 5. In all the years involved in sampling (2002, 2003 and 2004), condition factor was highest in April followed by May and June (1.57, 1.38 and 1.41). The only exception to this was a high value of 1.41 recorded in September 2003. Lowest values (1.12 and 1.11) 
were recorded in October 2002 and 2003 respectively. Generally condition factor was higher in rainy than dry season.

\section{Discussion}

The Integrated Method of [16] used for the analysis of length frequency data of H.odoe indicated that the growth is at first rapid, and then decreased with time. Previous studies of age and growth of fish have confirmed this assertion [31,32, 21, 14, and 33]. The Integrated curve on the length-frequency distribution produced modal lengths on the curve. The curve intersects each of the horizontal lines indicating 4 age groups.

Length frequency distribution has been used in estimating the age of many tropical fish species whose reproductive period is confined to a definite short period during the year [17, 21, 22, and 33].[34]Reported that age classes could be identified from length frequency histograms with sufficient accuracy. [16] Integrated Method expressed the length - at - age of the particular stock. The length - at - age determined is usually fit into the Von-Bertalanffy growth equation, highly popular among Fisheries Biologist [35, 36].

The Von-Bertalanffy model makes use of growth parameters $L_{\infty}, t_{0} k$, which are calculated or obtained graphically. It is the growth curvature parameter, $\mathrm{k}$ (which expresses how fast the fish approaches, $\mathrm{L}_{\infty}$ its determinate length if they are to grow to a very old age i.e. infinitely old fish) that is of immense value in the study of age and growth, $t_{0}$ is 'age' the fish would have at length zero i.e. time when fish has zero length. [37] Noted that some species, most of the short-lived, almost reach $\mathrm{L}_{\infty}$ in a year or two and have high value of $k$. Others could have a flat curve with low k-value and need many years to reach anything like $\mathrm{L}_{\infty}$.

The $\mathrm{k}-$ value $0.36 \mathrm{yr}^{-1}$ obtained in this present study indicates that the species is not like short-lived in the reservoir. From [37] were of the opinion that species that are short-lived are those whose k-values are $\geq$ $1.0 \mathrm{yr}^{-1}$. H.odoe could thus not say to be short lived in this Reservoir. This is equally confirmed from the theoretical maximal length, $\mathrm{L}_{\infty}$ of $35.3 \mathrm{~cm}$ observed.

The mean length $(23.35 \mathrm{~cm})$ of the year class $2^{+}$almost corresponded with the mean length of the species $(23.1 \pm 3.1 \mathrm{~cm})$ in the reservoir. Since the specimens were sorted and purchased from landing centres of local fishermen over a period of time, analysis of lengths based on such samples could have been influenced by many factors such as selectivity of fishing gear and availability of fish. This equally explains the comparatively very low occurrence of large H.odoe whose standard lengths were greater than $26 \mathrm{~cm}$ and small ones with standard length lower than $18 \mathrm{~cm}$. Small fishes are known to be captured by traps which are not used by fishermen in the reservoir. For objective and reliable information in stock assessment, [38] recommended the total removal methods, which favour electrofishing and poisoning or both at the same time. These methods of fishing are not allowed in Nigerian waters according to the Inland Fisheries Decree of 1992: Section 6. Mortality (Z) of H.odoe in the reservoir could be said to be low. This implies low exploitation of H. odoe in the reservoir. In fisheries, mortality is the most useful manner of expressing decay (= decrease) of an age group through time [39].

Statistical analysis of length-weight data showed that H.odoe exhibited positive allometric growth in Ado-Ekiti Reservoir; since the values of $\mathrm{b}$ (the exponent) of the regression equations for length-weight relationships were greater than 3. This finding is similar to that of Omotoyinbo (Unpublished) for H.odoe and [40] for Sarothrodon galilaeus in the same reservoir, suggesting that the reservoir is a good production habitat for fishes.

The condition factor showed the males to be healthier than females. This may be due to the fact that the feeding intensity (IF) of males was greater than females indicating that males consumed more food than females. This is similar to the report of [41] that the condition of the cichlids in Awba Reservoir was better when they consumed more food. Condition factor was more related to weight than length of $H$.odoe in AdoEkiti Reservior showing that weight of fish is a better measure of the state of well-being than length. Bigger fish were in better condition than smaller ones. The lower condition factor of 0.84 [42] reported from the population of $\mathrm{H}$. odoe from Eleyele Reservior implies that Ado-Ekiti Reservior is a better environment than Eleyele Reservoir for the species.There was seasonal variation in condition factor of H.odoe in Ado-Ekiti Reservoir. According to [43] such differences in monthly values of condition factor give information on availability and abundance of food supply and changes in seasons. 

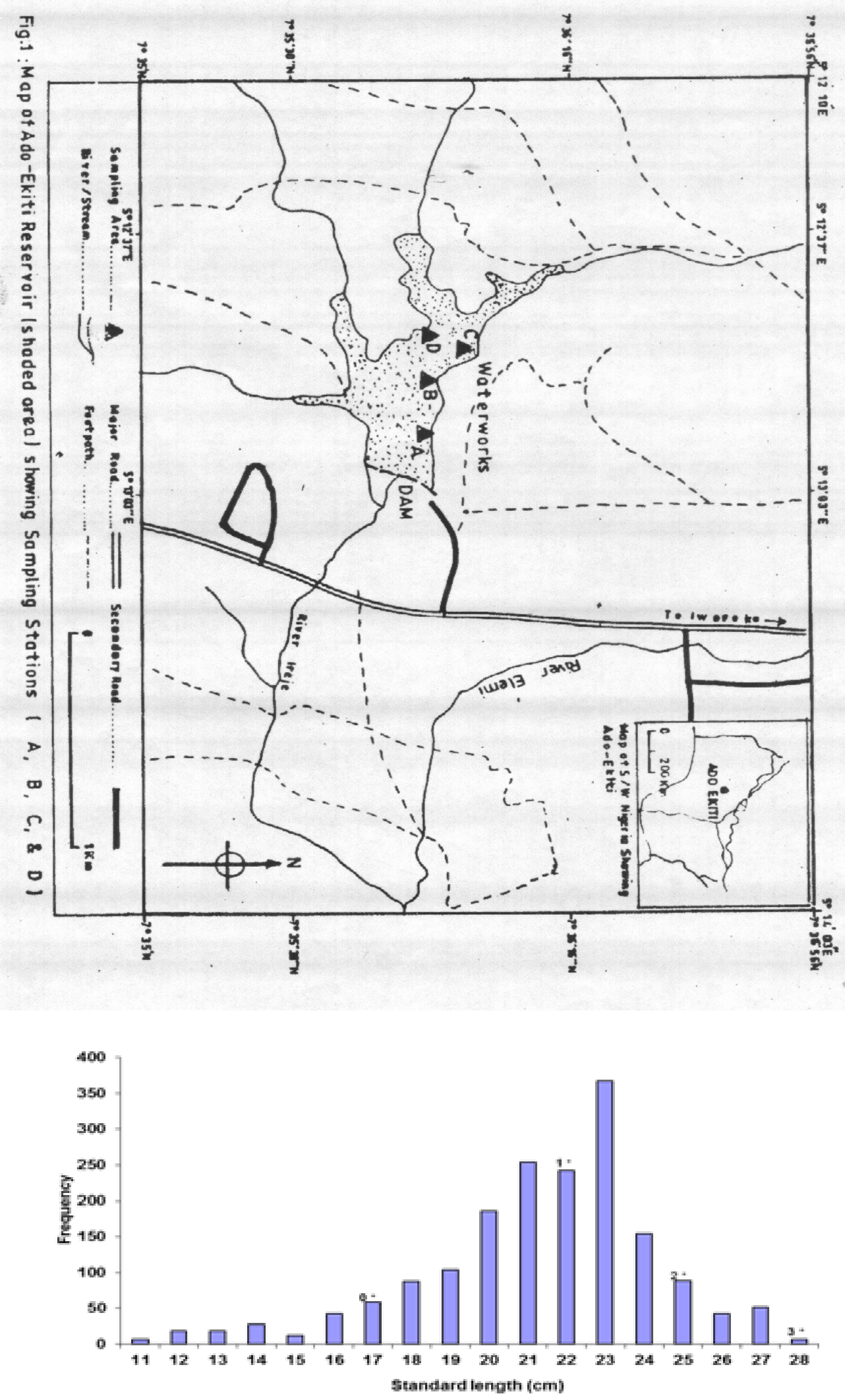

Figure 2: Length frequency data of Hepsetus odoe in Ado-Ekiti Reservoir showing peaks standing for age groups 


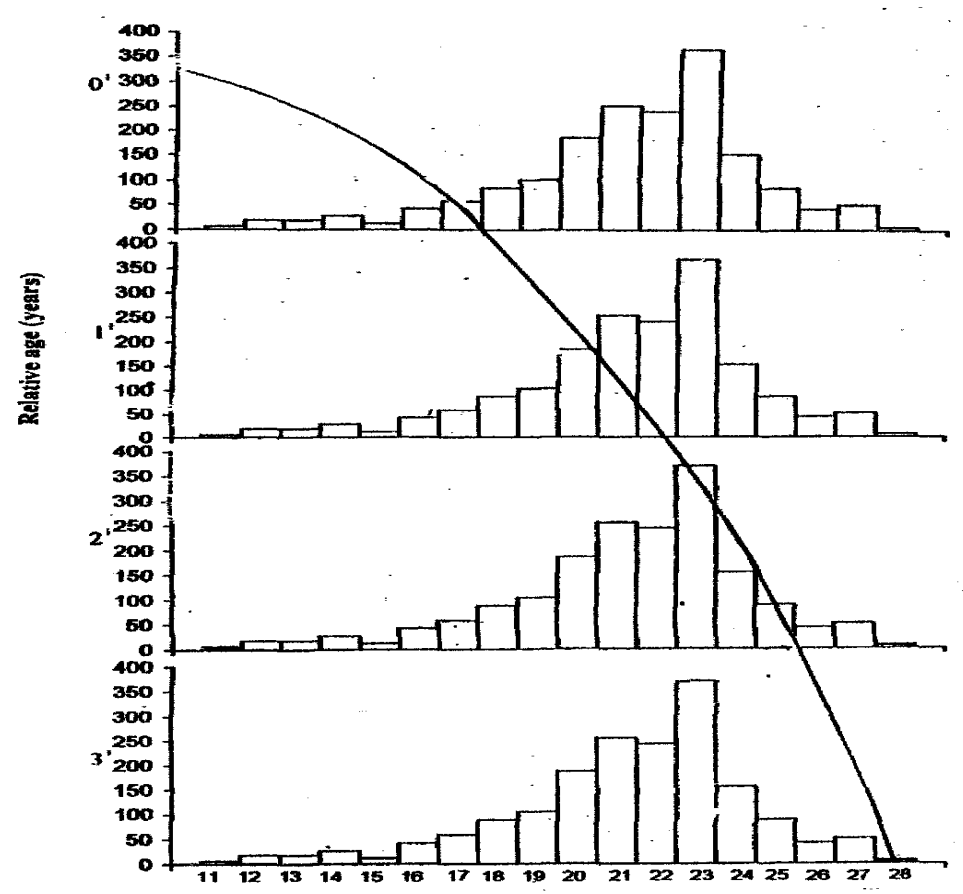

Figure 3: Age determination in Hepsetus odoe from Ado-Ekiti Reservoir using the Integrated Method

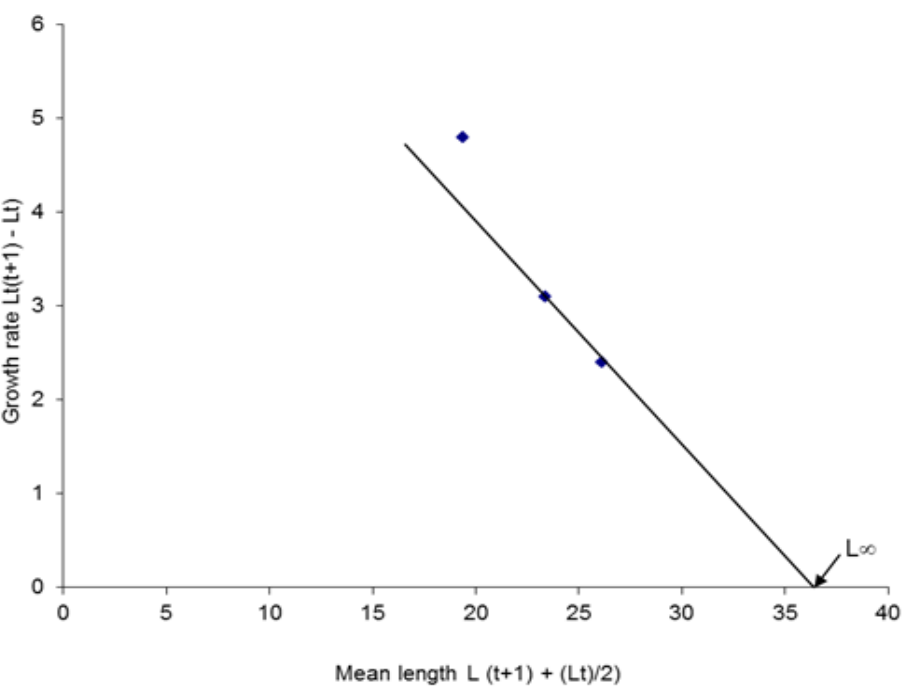

Figure 4: Gulland -Holt plot used in estimating the growth rate of Hepsetus

odoe in Ado-Ekiti Reservoir 




Figure 5: Monthly changes in condition Factor of Hepsetus odoe in Ado-Ekiti Reservior

Table1 Growth features corresponding to the age groups of Hepsetus odoe in Ado - Ekiti Reservoir

\begin{tabular}{llll}
\hline Age $(\mathrm{t} \mathrm{yrs})$ & $\mathrm{L}(\mathrm{t})=\mathrm{cm}$ & Growth rate $\mathrm{L}(\mathrm{t}+1)-\mathrm{Lt}=\mathrm{cm} / \mathrm{yr}$ & $\begin{array}{l}\text { Mean length } \mathrm{L}(\mathrm{t}+1)+\mathrm{L}(\mathrm{t}) / 2=\mathrm{Lt}= \\
\mathrm{cm}\end{array}$ \\
\hline $0^{+}$ & 17.00 & & \\
$1^{+}$ & 21.80 & 4.80 & 19.40 \\
$2^{+}$ & 24.90 & 3.10 & 23.35 \\
$3^{+}$ & 27.30 & 2.40 & 26.10 \\
\hline
\end{tabular}

\section{References}

[1]. W. Reed, J. Burchard, A.J. Hopson, J. Jenness and B. Yaro, Fish and Fisheries of Northern Nigeria ( Ministry of Agriculture, Northern Nigeria.1967) 226p.

[2]. Mc. Lowe and R.H. Connell, Fish communities in tropical fresh waters: their distribution, ecology and evolution (Longman London 1975) pp.337.

[3]. G. Bell - Gross, and J.L. Minshull, The Fisheries of Zimbabwe; Harare.: ( National Museums and Monuments of Zimbabwe, 1998).

[4]. G.S. Merron, K.K .Holden and M.N. Bruton, The reproductive biology and early development of the African pike, Hepsetus odoe, in the Okavango Delta, Botswana, Environmental Biology of Fishes 28, 1990, 215 - 235.

[5]. O. Kirk, O.Winemiller, C. Leslie and Kelso - Winemillar, Comparative ecology of the Africa pike, Hepsetus odoe, and tigerfish Hydrocynus forskahlii, in the Zambezi River Floodplain. Journal of Fish Biology: 45, 1994, 211-225.

[6]. G. Idodo - Umeh, Freshwater fishes of Nigeria, Taxonomy, Ecological notes, diet and utilization 2003, 232p.

[7]. E.O. Idowu, and A.A.A. Ugwumba, The food and feeding habits of African pike, Hepsetus odoe (Bloch, 1974) (Osteichtyes Hepsetidae) in Ado-Ekiti Reservoir, Nigeria. The Zoologist vol 1 (4), 2006, 7-17.

[8]. E.O.Idowu, Aspects of the Biology of African pike, Hespetus odoe (Osteichthyces; Hepsetidae) In Ado-Ekiti Reservior, Ph.D, Thesis, University of Ibadan, Nigeria, 2007. 198pp

[9]. E.O. Idowu and A.A.A. Ugwumba, Using Annuli on the Opercula Bones and Scales of African Pike (Hepsetus odoe) for Age Determination in Ado- Ekiti Reservior, Nigeria. Journal of Life Science 4, 7 (32) 2010, $34-38$ (USA).

[10]. H.W. Everhart, A.W. Eipper and W. Youngs, Principle of Fishery Science (Cornnel University Press 1975). 56 - 73.

[11]. A.H. Weatherley, and S.C. Rogers, Some aspects of age and growth of fresh water fish production (Academic Press London . Ed. Shelby. D. G.1978) $52-69$

[12]. G.A. Arawomo, The growth of Sarotherodon niloticus in Opa Reservior, University of Ife (Obafemi Awolowo University) Ile-Ife. Proceeding of Fisheries Society of Nigeria, 1982) 124pp.

[13]. P. Oben, A.Ugwumba, and S.O. Fagade, Age and growth studies of Hyperopisus bebe (Lacepede) (Mormyridae in Lekki Lagoon, Nigeria J. Afr. Zool. 112, 1998, 87 - 96.

[14]. P.M. Oben, and B.O. Oben, Age and growth studies of Mormyrops deliciosus (Leach) (Mormyridae) in Lekki Lagoon, Nigeria. The Zoologist Vol. 2(2), 2003, $55-67$.

[15]. O.O. Whenu and S.O.Fagade, The Morphology of The Scale of Parachanna obscura in River Owo Southwest Nigeria. Research Opinions in Animal \& Veterinary Science (roavs) 1(20), 2011, 107-111

[16]. D. Pauly, Some single simple method for the assessment of tropical fish stocks. FAO Fish Tech. Paper 234: 8, 1983,16pp.

[17]. S.O. Fagade, and C.I.O. Olaniyan, The Biology of the West African Shad Ethmalosa fimbriata (Bowdich in the Lagos Lagoon, Nigeria. J. fish Biol. 4,1972 519-533.

[18]. K. Ikusemiju, The Biology of the Bagrid Catfishes, from Lekki Lagoon, Ph.D Thesis, University of Lagos. Lagos 1973.

[19]. O.A.Ugwumba, Distribution and growth pattern of the tenpounder Elops (VAL) in the freshwater, estuarine and marine environments of Lagos, Nigeria. Arch. Hydrobiol 115(3), 1989, $451-462$.

[20]. P.M. Oben, and O.A.Ugwumba, Age and growth of Heterotis niloticus (Cuvier) from an inland tropical lake. Nig. Js. Y. Sci. $33,1999,85-89$.

[21]. P.M.Oben, O.A.Ugwumba, and S.O.Fagade, Using lunar rings on the opercular bones of Mormyrus rume (Cuview and Valenciennes), for age and growth determinations. Nig. J. of Sci. 33, 1999. $77-83$.

[22]. A.A.Ayoade, The Bionomics of Schilbe mystus (Linne, 1976) in Asejire and Oyan Lakes, Southwestern Nigeria, Ph.D. Thesis, Unversity of Ibadan ,2004, 275pp.

[23]. M.K. Adiase, A Preliminary report on the food of fish in the Volta Lake. In: Man made Lakes. The Accra Ed. Oben L.E.) Published for Ghana Academy of Sciences by Ghana University Press 1969. pp 237-238.

Symposium

[24]. A.M.A.Imevbore, and O. Bakae, The food and feeding habits of non-cichlid fishes of the River Niger in the Kainji Reservoir area. Kainji Lake studies I. (Ecology), Ed. SA. Viser ( published for NISER by the Ibadan University Press 1970) PP.87-98 
[25]. A.A.A. Ugwumba, and K. Kusemiju, The food and feeding habits of the non-cichlid fishes in the Lekki Lagoon Nig. J. of Sci; 28, 1994, $351-368$.

[26]. A. Agbeyo, Water Supply to Ado - Ekiti ,Research Report to Department of Geography, University of Ibadan, 1976,83pp.

[27]. S.O. Fagade, Age determination in Tilapia melanotheron (Ruphell) in Lagos Lagoon, Nigeria. The aging of T.B. BagenalEd.). Symposium Proceeding (Old working, Union Bros. Ltd. 1974) 243 PP.

[28]. L. Von - Bertalanffy, A quantitative theory of organic growth. Hum. Biol. 10, 1, 1983, $81-243$.

[29]. R.J.T. Beverton, and S.J. Holt, Manual of methods of fish stock assessment part 2 tables of yield functions. FAO Fish Technical Paper 38(1) 1996, 67pp.

[30]. S.O. Fagade, Observation on the biology of two species of Tilapia from the Lagos Lagoon, Nigeria Bull. De L. T.F.A.N.,Ser.A 3: $1979,628-653$

[31]. A.A. Olatunde, Some aspects of the biology of Synodontis schall (Bloch and Schneider) in Zaria, Nigeria. Journal of Aquatic Science 4,1989, 49-54.

[32]. W.R. Poole and J.D. Reynolds, Growth rate and age at migration of Anguilla J. Fish Biol. 48,1996, 623 - 642.

[33]. C. Ogueri, Physico-chemical parameters, fish fauna and fisheries of river Katsina Ala, Nigeria. Ph.D. Thesis. University of Ibadan.2004 351pp.

[34]. D.J. Warson, and E.K. Balon, Structure and production of fish communities in tropical rainforest streams. Canadian J. of Zool. $6,1984,927-940$.

[35]. D.W. Bowker, The bias association with dispersion of length at age in the estimate of growth and mortality parameters from unimodal length-frequency data. Journal of Fish. Biology 49: 1996,743-747

[36]. L. Vilizzi, and K.F. Walker, Age and growth of the common carp, Cyprinus carpio in the River Murray, Australia, Validation, Consistency of age interpretation and growth models. Environmental Biology of Fishes 54, 1990, $77-106$

[37]. P. Spare, E. Ursin and S.C. Venoma, Introduction to tropical fish stock assessment Part I manual FAO Fish Tech. Pap (306. 1), $1989,337 \mathrm{pp}$

[38]. R.L.Welcome, River Basins. FAO Fish Tech. Pap.(2002) 1983,60pp.

[39]. G.C. Achionye, Aging and growth of the cichlid, Sarotheroldon galealius (L) from IITA, Ibadan. Ph.D. Thesis, University of Ibandan, 1989, 344pp.

[40]. I.T. Omoniyi, and M.O.Bakare. Natural diets and Length-weight relationship of Sarotherodon galileaus (L) in Ado-Ekiti Reservoir, Ekiti State, Nigeria. Global J. Pure and Appl. Sc.1997.

[41]. Ugwumba, A.A.A.\&A. Adebisi, The food and feeding ecology of Sarotheron melanotheron (Ruppell) in a small fresh water reservoir in Ibadan. Archive of Hydrobiology 124.3:1992,367-382

[42]. A.I.O. Aleshinloye, Age and growth studies of fishes of Eleyele Reservoir Ibadan, Nigeria. M.Sc. Thesis, University of Ibadan.1999

[43]. K.F. Lagler, J. E. Bardachi ,R.R. Miller, and.R. Passino, : Ichthyology. ( John Wesley and Sons. N.Y.1977) 